\title{
THE EFFECT OF COLLABORATIVE STRATEGIC READING ON GRADE SIX STUDENTS' READING ACHIEVEMENT
}

\author{
Carolin Diana Sari \\ Elementary School (SD) Kristen Gloria 3 of Surabaya \\ (carolindianasari@gmail.com)
}

\section{Siti Tamah}

Widya Mandala Catholic University of Surabaya

(bamafam_mina@yahoo.com)

\begin{abstract}
One of the language skills to master by Indonesian EFL learners is reading. In order to assist learners comprehend reading texts, teachers are challenged to apply various teaching strategies. As this paper focuses on teaching reading, two teaching strategies dealing with reading instruction are compared. To be specific, in this paper the writers conduct a study to find the difference between Collaborative Strategic Reading (CSR) and teacher-centered teaching strategy (by applying skimming and scanning). This study was a quasi experimental, which was conducted upon the sixth graders of an elementary school. The finding showed that reading achievements of the students who are taught using CSR and teacher-centered teaching strategy are not significantly different. Nevertheless, this study using Cohen's d formula finds that CSR gave a small effect on students' reading achievement.
\end{abstract}

Key words: collaborative strategic reading; reading achievement

\section{ABSTRAK}

Salah satu kemampuan bahasa yang harus dikuasai oleh pembelajar Bahasa Inggris sebagai bahasa asing di Indonesia adalah membaca. Untuk membantu pembelajar memahami bacaan, guru-guru ditantang untuk menerapkan berbagai strategi mengajar. Karena artikel ini berfokus pada mengajar membaca, dua strategi mengajar membaca dibandingkan. Secara lebih spesifik, penulis melakukan penelitian untuk melihat perbedaan antara Collaborative Strategic Reading (CSR) dan teacher-centered teaching strategy (dengan menerapkan skimming dan scanning). Penelitian ini termasuk jenis kuasi eksperimen yang dilaksanakan kepada siswa-siswi kelas enam Sekolah Dasar. Hasil dari penelitian ini menunjukkan bahwa hasil membaca dari siswa-siswi yang diajar dengan menggunakan CSR dan teacher-centered teaching strategy tidak berbeda. Meskipun demikian, analisis Cohen's $d$ menunjukkan adanya efek yang kecil dari CSR terhadap kemampuan membaca.

Kata kunci: collaborative strategic reading, hasil belajar membaca

How to Cite: Sari, C., D. \& Tamah, S. (2015). The Effect of Collaborative Strategic Reading on Grade Six Students' Reading Achievement. IJEE (Indonesian Journal Of English Education), 2(1), 17-26. doi:10.15408/ijee.v2i1.1501

Permalink/DOI: http://dx.doi.org/10.15408/ijee.v2i1.1501 


\section{INTRODUCTION}

People do not automatically learn how to read. Reading has to be learned and taught intentionally (Iftanti, 2012). This has been argued earlier by Nunan (1999) pointing out that reading is not something individually learned. It is even argued that teachers spend more time teaching reading than teaching any other skills (Nunan, 1999, p. 249). It is then good to know that various techniques for teaching reading have been created to assist students in reading, which have been claimed to be very advantageous not only in offering the fun or entertainment in the classroom but also in improving students' academic performance.

Marzano, Pickering and Pollock (2001) found nine categories of instructional strategies that have a strong effect on student achievement in all subject areas at all grade levels. One of them is Cooperative Learning. Implicit is that Cooperative Learning strategy can be implemented as early as possible for elementary school students. This group work-based instruction or the one which falls within the more general category of "grouping" strategies (Marzano, Pickering \& Pollock, 2001, p. 85) has its extensively claimed merits, such as increasing student talking time, encouraging co- operation and allowing students to work on various tasks (Harmer, 2012).

As EFL learners, elementary school students are given English subject to enable them read texts at their level. Similarly argued, reading instruction to EFL young learners is not only aimed at introducing literacy to them but also aimed at, more crucially, assisting them in learning and acquiring English.

Conventionally the teaching of reading is a teacher-centered instruction. This typical whole class teacher directed instruction is, Harmer (2007) argued, still the most common teacher-student interaction in many cultures. This whole class teaching is not without its own merits. It helps, among others, build class spirit, the feeling that every student is involved (Harmer, 2012). As this teachercentered instruction forces students to do the same thing at the time and at the same pace (Harmer, 2007), teachers are encouraged to shift to the learnercentered instruction, where small groups are frequently formed enabling the students to, among others as found by Tamah (2011), provide the opportunity for the students to come up with a better formulated main idea when discussing a text.

Not all students at school like reading. Some students show 
enthusiasm when they meet reading texts. However, some students show 'rejection'. Therefore, various strategies for teaching reading should be introduced. In this study, the writers examine the difference between Collaborative Strategic Reading (CSR) and teacher centered teaching strategy (by applying skimming and scanning). To be more specific, this study investigates the effect of collaborative strategic reading on students' reading achievement.

The writers have determined two research questions. The first is whether there is a significant difference between students who are taught using Collaborative Strategic Reading and students who are taught using teacher centered teaching strategy in their reading achievement with regard to knowledge and comprehension levels. The second is whether Collaborative Strategic Reading gives a big effect to the students in the experimental group. Collaborative Strategic Reading is a reading comprehension strategy found by Klingner and Vaughn in 1987. This strategy combines modification of Reciprocal Teaching and cooperative learning strategy (Abidin \& Riswanto, 2012).

Furthermore, Klingner and Vaughn (1998) state that Collaborative Strategic Reading is a strategy in teaching by engaging students to work cooperatively. Collaborative Strategic Reading is a teaching strategy which consists of four steps, namely preview, click and clunk, get the gist, and wrap up.

'Preview' is done before the reading. The teacher asks the students to predict what they are going to read based on the topic or title given. 'Click and clunk' and 'get the gist' are the steps the students do during reading. The students and the teacher discuss difficult parts of the text and find important aspects of the text. Finally, 'wrap up' is done after reading. The teacher gives questions to know the students' understanding about the text.

Three phases of this particular strategy instruction include modeling phase, teacher-assisted phase, and independent phase (Klingner, 1998). In modeling phase, the teacher presents each of the strategies (preview, click and clunk, get the gist, and wrap up) to the whole class while the students watch the teacher's demonstration. In teacherassisted phase, the teacher guides the students through the strategy in union or in small groups. The students try to apply preview, click and clunk, get the gist, and wrap up under teacher guidance. In independent phase, the students complete the strategies (preview, click and clunk, get the gist, and wrap up) as well as apply the roles which have been 
assigned to each member of the group (leader, clunk expert, gist expert, questions expert, encourager, and time keeper). As it is expected to be an independent phase for the students, the teacher's guidance becomes less intense.

Backiel (2009) considers that in a teacher-centered strategy the teacher's role is to transfer knowledge to be learned. The teacher is the center who dominates the teaching learning processes. The teacher takes most part of the processes and the students have limited access. Furthermore, the teacher gives the same pattern of questions for the students as what Slavin (as cited in Tamah, 2011, p.1) argues that grammar point is prevalently explained using the same instructional pace. Similarly, Huba and Fred (2000) consider that in teacher-centered teaching strategy, students receive information passively and the teacher is the primary information giver as well as evaluator, the classroom tends to be quiet, and the culture tends to be competitive and individualistic. They add that this approach reflects teacher's anxiety and distrusts students' ability to work independently. As a result, this approach gives negative impact toward classroom behavior. This conventional mode of instruction is then to be employed in the control group and compared to CSR in the experimental group as described in the method section.

\section{METHOD}

This was a quasi-experimental study employing a pre- and post-test design. The population of this study was 72 grade six students of ' $Z$ ' Elementary School in their second semester of 2013-2014 academic year. The writers chose the sixth graders because of some reasons. First, one of the writers taught them. Even though the treatment was done by the other English teachers, it was helpful in adjusting the school materials with the time. Second, Mohammed et al. (2010) says that CSR works in classroom from the third grade through middle school. This study was held in the sixth grade.

The writers took two classes which became the control group and experimental group. They were randomly taken from two out of the three classes available. There were 24 students in the experimental group and also 24 students in the control group.

To obtain the data, the writers used a reading test that consisted of three texts and 30 questions of multiple choice type. The questions consisted of five knowledge and five comprehension questions for each text. The average length of the text was about 290 words. The texts were of 
narrative genre. The reading test was used as the pretest and posttest. The same test was given to the students in both groups. The total score of the test was 30 .

The topics which were used during treatments were the same as the topics taught in the classroom. The English teacher who was assigned to teach in both groups were provided with the lesson plans prepared by the writers. Both groups got the same reading texts, but some exercises were different. For example, when the text entitled Fresh Painting was discussed, the students in the experimental group got five comprehension questions in the form of answering questions, while students in control group got them in the form of completing sentences. Even though they were not the same, the aim was the same that is to measure students' achievement in knowledge and comprehension levels.

Before the pretest was used in the actual study, the writers did the try-out. In the first try-out the reliability was good enough, but the result of the level of difficulty and item discrimination were not satisfying. The second try-out was held and a better result with regard to item difficulty and item discrimination was revealed. The test reliability of 0.82 was obtained.
The treatment was done twelve times in each of the experimental and control groups with the time limitation of 40 minutes at ' $Z$ ' elementary school in Surabaya from January 6, 2014 to January 30, 2014. There was a pretest before the treatments and a posttest after the treatments in both groups.

The treatments between experimental group and control group were not the same. The technique used in the experimental group was Collaborative Strategic Reading which had three phases i.e. modeling phase, teacher assisted phase and independent phase. Those phases took three meetings. Meanwhile, the technique which was used in the control group was skimming and scanning. As a conventional technique, it did not have particular phases to be introduced to the students. The treatments in the control group was designed to accommodate teacher centered teaching strategy.

To test the first hypothesis, which states if there is a significant difference between students who are taught using Collaborative Strategic Reading and those who are taught using teacher centered teaching strategy in mastering knowledge and comprehension level, the writers employed a t-test. Hatch and Lazaraton (as cited in Tamah, 2000) argue that it is important to check the 
normality of the distribution when $t$-test is used. Therefore, the pretest as well as the post-test scores were checked for their normal distribution and equal variances. When normal distribution and equal variances were not met, nonparametric tests would be employed.

The pretest scores of the experimental group computed using Kolmogorov-Smirnov test and ShapiroWilk test showed $\mathrm{p}=.200$ and .227 respectively. Since $\mathrm{p}=.200$ and .227 were greater than .05 (the level of significance determined), the data were considered taken from normally distributed population.

Similarly, the pretest scores of the control group were also checked for their distribution using KolmogorovSmirnov test and Shapiro-Wilk test. The findings showed the significance level was at $\mathrm{p}=.200$ and .351 respectively. Since $p=.200$ and .351 were greater than .05 (the level of significance determined), the data were considered taken from normally distributed population. In summary, the pretest scores of both groups were then proved to be normally distributed.

To test the second hypothesis, which assumes that there is an effect of Collaborative Strategic Reading on students' achievement in the experimental group, the writers applied Cohen $d$ formula.

\section{FINDINGS AND DISCUSSION}

The calculation on the pretest of both groups indicated that the variance estimate for experimental group was 26.34 and control group was 29.93. Then the F-ratio obtained was .880. The $d f$ for mean squares was 23 ( $F$ table of 2.19 is required at .05 level of significance). Since the obtained F was smaller than $\mathrm{F}$ value shown in the table, the homogeneity of the variance was confirmed. In brief, the data were of equal variance.

Since the data were normally distributed and had equal variances, the $t$-test for independent samples was used to find whether the two groups had equal reading ability before the treatment was given.

Table 1. The Result of the t-test for the Pretest Scores of the Experimental and

Control Groups and Control Group

\begin{tabular}{llllll}
\hline Variables & $\begin{array}{c}\text { Me } \\
\text { an }\end{array}$ & $\begin{array}{c}\text { Obtai } \\
\text { nedt }\end{array}$ & $\begin{array}{c}\boldsymbol{d} \\
f\end{array}$ & $\begin{array}{c}\boldsymbol{t} \\
\text { tabl } \\
\boldsymbol{e}\end{array}$ & $\begin{array}{c}\text { Conclus } \\
\text { ion }\end{array}$ \\
\hline Experime & 20.5 & .008 & 4 & 2.02 & Not \\
ntal & 19.2 & & 6 & 3 & Signific \\
Group & 5 & & & $(\mathrm{a}=0$ & ant \\
Control & & & & $.5)$ & \\
Group & & & & & \\
\hline
\end{tabular}

Table 1 showed that the mean for experimental group was 20.5 while for control group was 19.25 and the obtained $t$ was .008 . At .05 level of significance $(d f=46)$ the $\mathrm{t}$ table showed 
the value of 2.023 as the critical value to decide the difference. Since the obtained $t(.008)$ was less than 2.023 (the $t$ table), it is concluded that the pretest mean score of both groups were not significantly different. Therefore, an important condition for an experimental study, i.e. the same background knowledge of both experimental and control groups is met in this study.

The posttest scores of the experimental group computed using Kolmogorov-Smirnov test and ShapiroWilk test showed $\mathrm{p}=.038$ and .010 respectively. Since $\mathrm{p}=.038$ and .010 were not greater than .05 (the level of significance determined), the data were not considered taken from normally distributed population.

The posttest scores of the control group computed using KolmogorovSmirnov test and Shapiro-Wilk test showed $p=.087$ and .046 respectively. Since $p=.087$ was greater than .05 and .046 was not greater than .05 (the level of significance determined), the data were considered taken from normally distributed population.

The calculation on the posttest scores of both groups indicated that the variance estimates for the experimental group and the control group were 12.89 and 27.94 respectively. The F-ratio obtained was .461. The $d f$ for mean squares was 23. (In F distribution table, the $\mathrm{F}$ table of 2.19 is required for significance at .05 level). Since the obtained $F$ was smaller than $F$ value shown in the table, the homogeneity of the variance was confirmed. In brief, the data were of equal variance.

The data above showed that posttest scores of both groups were not normally distributed, but they were of equal variances. Instead of the t-test for independent samples, the nonparametric test (Mann-Whitney U) was then used to estimate the difference between the experimental group and the control group in their posttest scores.

Table 2. Calculation of Nonparametric Test (Mann-Whitney U) of the Posttest

Scores between Experimental and Control Group

\begin{tabular}{lr}
\hline \multicolumn{2}{c}{ Test Statisticsa } \\
\hline & Posttest \\
Mann-Whitney U & 197.500 \\
Wilcoxon W & 497.500 \\
Z & -1.879 \\
Asymp. Sig. (2-tailed) & .060 \\
a. Grouping Variable: group & \\
\hline
\end{tabular}

The analysis as shown in the above Table 2 reports that significance level was at $p=.060$, which was greater than .05 . This findings mean that there was no significant difference between the post test scores of the experimental group and the control group. 
Consequently, the first hypothesis proposed in this study is rejected.

The next question raised in this study was whether CSR gives an effect to students' achievement in reading comprehension, which analysis is described in Table 3. In addition to the Cohen's $d$ analysis, the percentage of the gain score was also calculated.As seen in Table 3, there was $15.85 \%$ of improvement in the experimental group from their pretest scores to their posttest scores. Table 3 also shows that the improvement of the control group was lesser, which was only $9.71 \%$.

Table 3. Tendency of CSR to be More Helpful

\begin{tabular}{lccc}
\hline & \multicolumn{2}{c}{ Mean } & Gain \\
\cline { 2 - 3 } & pretest & posttest & \\
Experimenta & 20.5 & 23.75 & $15.8 \%$ \\
1 Group & & & \\
Control & 14.25 & 21.12 & $9.71 \%$ \\
$\quad$ Group & 14.25 \\
\hline
\end{tabular}

Although the amount of the improvement of the experimental group was bigger than that of the control groups, concerning the effect, the Cohen's $d$ formula showed that the effect of the experimental group was only $d=0.24$, which means that the effect is small. Therefore, the second hypothesis of the study was also rejected.

To guide the study, the writers have proposed two main research questions. The questions of the study are determined to see if there is a significant difference between students who are taught using Collaborative Strategic Reading and students who are taught using teacher centered teaching strategy in their reading achievement with regard to knowledge and comprehension levels. The second question of the study concern the effect of Collaborative Strategic Reading on students' achievement in the experimental group.

To provide a tentative answer to those research questions, the writers formulated two alternative hypotheses, which were 1) there was a significant difference between reading achievement of the students who are taught using Collaborative Strategic Reading and those who are taught using teacher centered teaching strategy in mastering knowledge and comprehension level, and 2) Collaborative Strategic Reading gave a big effect to the students in the experimental group.

After the statistical analysis on the pretest scores was carried out, it was found that both experimental and control groups had equal reading ability before the treatment.

In the experimental group, the treatment was planned to let the students engaged most of the time in doing CSR. It was clear that the students comprehended the text by 
having discussion in group based on their roles. On the other hand, in the control group the treatment was planned to maintain teacher centered teaching strategy, the traditional way of teaching reading by allowing the students to comprehend the text using skimming and scanning techniques individually.

The result of the posttest scores calculated using Mann Whitney $U$ test indicated that the formulated hypothesis was rejected. This present study revealed that the CSR technique did not show significantly higher result than teacher centered teaching strategy. The present study then suggests that for comprehending a text, there is no significant difference between the implementation of CSR and the teacher centered teaching strategy in assisting students to comprehend reading texts at the levels of knowledge and comprehension. The posttest scores performed by the students applying CSR was more or less the same as that performed by the students taught by teacher centered teaching strategy.

Concerning the effect, the pretest mean score of the experimental group was 20.5 while the posttest mean score was 23.75. The pretest mean score of the control group was 19.25 while the posttest mean score was 21.12. From these numbers, the gain score of the experimental group (15.85\%) was greater than that of the control group (9.71\%). This fingding could be used to assume that CSR helped the students to improve their comprehension more.

Nevertheless, the result of the Cohen's $d$ analysis revealed that the effect was limited to $d=0.24$. Cohen as cited by Morzano et.al (2001) considered that an effect size of .20 can be considered as small, while an effect sizes .50 and .80 are considered medium and large respectively. Therefore, the effect size of the use of CSR in improving students' reading comprehension was small.

Some possible explanation for this finding might the fact that the students did not have good ability in reading as in listening, speaking, and writing. Moreover, the students were getting bored after several meeting continuously with the reading class. As the result they answered the comprehension questions just as their obligation in order to fulfill teacher's instructions.

\section{CONCLUSION AND SUGGESTION}

This study has found that there is no significant difference between the students who are taught using Collaborative Strategic Reading and the students who are taught using teacher centered teaching strategy in their 
reading achievement with regard to knowledge and comprehension levels. It is also found that Collaborative Strategic Reading gives a small effect to the students in the Experimental Group.

As this study was conducted in an elementary school where the type of reading text is limited, future study might be held in higher levels of education which allow various types of reading texts.

\section{REFERENCES}

Abidin, M. J.Z., \& Riswanto. (2012). Collaborative Strategic Reading (CSR) within cognitive and metacognitive strategies perspective. European Journal of Business and Management, 4, 61-69.

Backiel. (2009). Teacher-Centered Strategies. Retrieved from https://prezi.com/4ua0anbnwwj $\mathrm{v} /$ teacher-centered-strategies/

Harmer, J. (2012). Essential teacher knowledge: Core concepts in English language teaching. Pearson Edu. Limited.

Huba, M. E. \& Fred, J. E. (2000). Learnercentered assessment on college campuses. Retrieved fromhttp://assessment.uconn/do cs/TeacherCenteredVsLearnerCe nteredParadigms.pdf.
Iftanti, E. (2012). A survey of the English reading habits of EFL students in Indonesia. TEFLIN Journal,23(2), 149-164.

Klingner, J. K., \& Vaughn, S. (1998). Using Collaborative Strategic Reading. Teaching Exceptional Children, 32-37. Retrieved from http://www.utexas.edu/cola/ce nters/tlc/_files/conferences/new medianewmaterials/using_collab orative.pdf.

Marzano, R. J., Pickering, D. J., \& Pollock, J. E. (2001). Classroom instruction that works: Researchbased strategies for increasing student achievement. Alexandria: Association for Supervision and Curriculum Development.

Mohammed, S. S., Swanson, E., Roberts, G., Vaughn, S., Klingner, J. K., \& Boardman, A. G. (2010). The effects of Collaborative Strategic Reading instruction on the reading comprehension of middle school students. SREE Conference Abstract Template, 1-5.

Nunan, D. (1999). Second language teaching and learning. Boston: Heinle \& Heinle Publishers. 
Tamah, S.M. (2000). The effect of in-class proofreading on students' composition. (Unpublished Thesis). Universitas Negeri Surabaya, Indonesia.
Tamah, S. M. (2011). Student interaction in the implementation of the Jigsaw Technique in language teaching. (Published doctoral thesis). The University of Groningen, Groningen, the Netherlands. 